\title{
Effect of forty-eight-hour glucose infusion into rats on islet ion fluxes, ATP/ADP ratio and redox ratios of pyridine nucleotides
}

\author{
H P T Ammon ${ }^{1}$, M Bacher ${ }^{1}$, W F Brändle ${ }^{1}$, A Waheed $^{2}$, \\ M Roenfeldt ${ }^{1}$, M E El-Sayed ${ }^{3}$, A A E Ahmed ${ }^{4}$ and M A Wahl ${ }^{1}$ \\ ${ }^{1}$ Department of Pharmacology, Institute of Pharmaceutical Sciences, University of Tübingen, Tübingen, Germany, ${ }^{2}$ Ayub Medical College, Abbottabad, \\ Pakistan, ${ }^{3}$ Department of Pharmacology, Faculty of Pharmacy, University of Cairo, Cairo, Egypt and ${ }^{4}$ Department of Pharmacology, National Research \\ Centre, Dokki, Cairo, Egypt \\ (Requests for offprints should be addressed to H P T Ammon, Department of Pharmacology, Institute of Pharmaceutical Sciences, University of Tübingen, \\ Auf der Morgenstelle 8D, 72076 Tübingen, Germany)
}

\begin{abstract}
Glucose infusion into rats has been shown to sensitize/ desensitize insulin secretion in response to glucose. In pancreatic islets from glucose-infused rats (GIR) ( $48 \mathrm{~h}$, $50 \%, 2 \mathrm{ml} / \mathrm{h})$ basal insulin release $(2.8 \mathrm{mmol} / 1$ glucose $)$ was more than fourfold compared with islets from salineinfused controls and the concentration-response curve for glucose was shifted to the left with a maximum at $11 \cdot 1 \mathrm{mmol} / \mathrm{l}$. The concentration-response curve for ${ }^{45} \mathrm{Ca}^{2+}$ uptake was also shifted to the left in islets from GIR with a maximum at $11.1 \mathrm{mmol} / 1$ glucose. Starting from a high basal level at $2.8 \mathrm{mmol} / 1$ glucose $\mathrm{KCl}$ produced no insulin release or ${ }^{45} \mathrm{Ca}^{2+}$ uptake in islets from GIR. Islets from GIR exhibited a higher ATP/ADP ratio in the presence of $2.8 \mathrm{mmol} / \mathrm{l}$ glucose and marked inhi-
\end{abstract}

bition of ${ }^{86} \mathrm{Rb}^{+}$efflux occurred even at $3 \mathrm{mmol} / 1$ glucose. Moreover, in islets from GIR the redox ratios of pyridine nucleotides were increased. On the other hand insulin content was reduced to about $20 \%$.

The data suggest that a 48-h glucose infusion sensitizes glucose-induced insulin release in vitro in concentrations below $11.1 \mathrm{mmol} / 1$. This may, at least in part, be due to enhanced glucose metabolism providing increased availability of critical metabolic factors including ATP which, in turn, decrease the threshold for depolarization and therefore calcium uptake. Calcium uptake may then be further augmented by elevation of the redox state of pyridine nucleotides.

Journal of Endocrinology (1998) 156, 583-590

\section{Introduction}

Long term exposure of pancreatic islets to high glucose in vitro or by glucose infusion has been shown to cause sensitization and/or desensitization of insulin release (Leahy et al. 1986, 1987, Bolaffi et al. 1988, Marynissen et al. 1990, Timmers et al. 1990, Bedoya \& Jeanrenaud 1991a, Thams 1991, Davalli et al. 1992, Eizirik et al. 1992, Purello et al. 1992, Thibault et al. 1993). The respective effects seem to depend on the glucose concentration employed (Leahy et al. 1986) and the duration of glucose action (Bedoya \& Jeanrenaud 1991a). The effects appear to be reversible on return to normal glucose or mild hypoglycemia (Leahy \& Weir 1991, Svensson \& Hellerström 1991).

Glucose-induced insulin secretion is closely related to the metabolism of glucose through the formation of critical metabolic products including ATP (Cook \& Hales 1984, Malaisse \& Sener 1987) and reduced pyridine nucleotides (Ammon \& Wahl 1994). Both are thought to be responsible for initiation and/or modulation of insulin secretion by acting on $K_{\mathrm{ATP}}$ and/or calcium channels (Henquin \&
Meissner 1984, Boyd 1992, Ammon \& Wahl 1994). Since long term exposure of pancreatic islets has been reported to enhance islets glucose metabolism (Bedoya \& Jeanrenaud 1991a, Purello et al. 1992, Chen et al. 1994) it was aimed to study whether or not sensitization of insulin release to glucose and $\mathrm{KCl}$ caused by a 48 -h glucose infusion into rats may be explained by respective changes in critical metabolic products including the ATP/ADP ratio and the redox ratios of pyridine nucleotides and subsequent alterations in $\mathrm{K}^{+}$efflux (measured as ${ }^{86} \mathrm{Rb}$ efflux) and ${ }^{45} \mathrm{Ca}^{2+}$ uptake.

\section{Materials and Methods}

\section{Animals}

Female Wistar rats weighing between 250 and $300 \mathrm{~g}$ were used. The rats had free access to tap water and a standard pellet diet (Altromin 1324, Altromin-Futterwerk, Lage, Germany) and were kept at $22^{\circ} \mathrm{C}$ with a $12 \mathrm{~h}$ light-darkness cycle during the whole experimental period. 


\section{Glucose infusion procedure}

For implantation of chronic catheters, the rats were anesthetized with Ketamin (Ketanest, Parke-Davis, Freiburg, Germany, 45 mg/kg i.p.) plus Rompun (Bayer, Leverkusen, Germany, $12 \mathrm{mg} / \mathrm{kg}$ i.p.). Silastic medicalgrade tubing (Dow Corning, Midland, MI, USA) was filled with a solution of $0.9 \% \mathrm{NaCl}$ supplemented with $5000 \mathrm{IU} / \mathrm{ml}$ heparin (Liquemine, Roche, Grenzach, Switzerland), inserted via the right jugular vein into the right atrium. The free end was routed subcutaneously and externalized between the shoulders through a teflon anchoring device which was sewn to the skin. The catheter was then routed through a bite-proof stainlesssteel spiral fixed to an oscillating arm connected to a swivel allowing the rat to move freely. Infusion of $0.9 \%$ $\mathrm{NaCl}(0.5 \mathrm{ml} / \mathrm{h})$ was administered for a recovery period of 48 h. Then glucose solution $(50 \%$ glucose, Fresenius, Bad Homburg, Germany) supplemented with $0.45 \% \mathrm{NaCl}$, or $0.45 \%$ saline (control) was continuously infused at a rate of $2.0 \mathrm{ml} / \mathrm{h}$ for $48 \mathrm{~h}$ with a Perfusor syringe pump (Braun, Melsungen, Germany). Complete infusions over a period of $48 \mathrm{~h}$ were achieved in more than $95 \%$ of cases with this technique. Blood samples were obtained from the tail vein.

\section{Blood glucose and plasma insulin assays}

Blood glucose was measured by the hexokinase method (Glucoquant, Boehringer, Mannheim, Germany) and plasma insulin by radioimmunoassay (double antibody method, Linco Research, St Louis, MO, USA) using rat insulin (Novo Research, Bagsvaerd, Denmark) as a standard. ${ }^{125} \mathrm{I}$-insulin was a kind gift from Hoechst AG (Frankfurt, Germany).

\section{Preparation of islets}

After a 48-h infusion of glucose (glucose-infused rats (GIR)) or saline (saline-infused rats (SIR)) islets were isolated by the collagenase method (Lacy \& Kostianovsky 1967). Since islets were exposed to different blood glucose concentrations during the $48-\mathrm{h}$ infusion period, i.e. approximately $11.1 \mathrm{mmol} / 1$ in GIR and $5.6 \mathrm{mmol} / 1$ in SIR, we performed islet preparation steps, including preincubation, for islets of GIR in the presence of $11.1 \mathrm{mmol} / 1$ glucose and for islets of SIR in the presence of $5.6 \mathrm{mmol} / 1$ glucose in order to keep them in the same glucose environment until testing for various parameters. In a further control experiment we also prepared islets from SIR in the presence of $11.1 \mathrm{mmol} / 1$ glucose.

The pancreas was distended with KrebsRinger-HEPES (N-2-hydroxyethyl-piperazine-N'-2ethanesulfonic acid) (Roth, Karlsruhe, Germany) buffer, supplemented with glucose (see below) at room temperature and the tissue was cut into small pieces and digested with collagenase (Worthington, Freehold, USA, $30 \mathrm{mg}$,
$213 \mathrm{U} / \mathrm{mg}$ ) for $10-12 \mathrm{~min}$ at $37^{\circ} \mathrm{C}$ in a shaking water bath. The islets were collected with siliconized constriction pipettes under a stereomicroscope. The average yield of the isolation procedure was about 400 islets/pancreas. One hundred and fifty islets of the best visual quality and medium size were used for the experiments.

\section{Insulin secretion}

Insulin secretion was tested using the batch incubation method with five islets in $1 \mathrm{ml}$ medium per batch. The incubation time was $60 \mathrm{~min}$. Radioimmunoreactive insulin was determined with the double antibody method using rat insulin as a standard (Morgan \& Lazarow 1963, Soeldner \& Slone 1965).

${ }^{45} \mathrm{Ca}^{2+}$ net uptake

Net uptake of ${ }^{45} \mathrm{Ca}^{2+}$ was studied according to the method described by Henquin (1980). Batches of 10 islets were placed in polyethylene microfuge tubes together with $0.1 \mathrm{ml}$ Krebs-Ringer-HEPES buffer. At time zero, $0.05 \mathrm{ml}$ medium with ${ }^{45} \mathrm{CaCl}_{2}$ (Amersham-Buchler, Braunschweig, Germany) $(0 \cdot 80 \mathrm{MBq} / \mathrm{ml})$ and substances to be tested were added. Both tubes and media were prewarmed before starting the incubation. After $5 \mathrm{~min}$, islets were separated from the surrounding medium by centrifugation through a layer of $0.1 \mathrm{ml}$ silicone oil into $0.01 \mathrm{ml} 3 \mathrm{~mol} / 1 \mathrm{KOH}$ both being already present during the incubation. The bottom of the tube with the islets was cut off and transferred into scintillation vials. ${ }^{45} \mathrm{Ca}^{2+}$ content was determined by liquid scintillation counting after disappearance of luminescence. Results were calculated as pmol total $\mathrm{Ca}^{2+}$ after having subtracted blanks and corrected for label in the extracellular $\left[{ }^{3} \mathrm{H}\right]$ sucrose space.

\section{${ }^{86} \mathrm{Rb}^{+}$efflux}

${ }^{86} \mathrm{Rb}^{+}$is a tracer in studies of $\mathrm{K}^{+}$efflux. ${ }^{86} \mathrm{Rb}^{+}$efflux, now a standard technique, was measured as previously described by our group (Ammon et al. 1985) and by others (Henquin 1977). Briefly, groups of 40 islets were first incubated for $90 \mathrm{~min}$ in Krebs-Ringer-bicarbonate buffer containing $0.2 \mathrm{mmol} / 1{ }^{86} \mathrm{RbCl}$ (Amersham-Buchler) $(16 \cdot 6-21 \cdot 1 \mathrm{GBq} / \mathrm{mmol}$ specific activity) in the presence of 5.6 (controls) and $11.1 \mathrm{mmol} / 1$ glucose. After brief washing, islets were placed into perifusion chambers $(0.3 \mathrm{ml})$ to which the perifusate was conveyed at $37^{\circ} \mathrm{C}$ and a flow rate of $1.1 \mathrm{ml} / \mathrm{min} .{ }^{86} \mathrm{Rb}^{+}$appearing in the effluent fractions (collected at 2-min intervals) and remaining in the islets at the end of the experiment was counted by liquid scintillation. For each collection interval, the fractional efflux of ${ }^{86} \mathrm{Rb}^{+}$was calculated.

\section{Pyridine nucleotides}

The contents of total islet NADPH and NADP were assayed by a fluorimetric technique according to the 
principles described by Passonneau and Lowry (1974). At the end of the incubation period, the glass tubes were placed in an ice bath, and medium around the islets was immediately removed by aspiration. For the determination of $\mathrm{NADPH}$ and $\mathrm{NADH}$, islets were then immediately disintegrated in $20 \mu \mathrm{l}$ of a mixture of $0.5 \mathrm{mmol} / 1$ cysteine and $40 \mathrm{mmol} / \mathrm{l} \mathrm{NaOH}$ and heated for $15 \mathrm{~min}$ at $60{ }^{\circ} \mathrm{C}$. For the determination of NADP or NAD only $5 \mu l$ of this mixture was used, and $50 \mu \mathrm{l}$ of a mixture of $\mathrm{H}_{2} \mathrm{SO}_{4}$ (39 mmol/l) and $\mathrm{Na}_{2} \mathrm{SO}_{4}(0 \cdot 15 \mathrm{mmol} / \mathrm{l})$ were added and heated for $30 \mathrm{~min}$ at $60^{\circ} \mathrm{C}$. The pyridine nucleotides were determined from calibration curves prepared from authentic NADPH, NADP, NADH and NAD (Boehringer) taken through the same procedures. Disintegration of islets was assessed by microscopy. Recovery of NADPH added in various amounts to disintegrated islets was $97 \pm 4 \%$ (mean \pm s.E.M., $n=6$ ). Since NAD, NADH, NADP and NADPH were determined in different batches of islets it was not possible to calculate S.E.M. for totals and ratios of pyridine nucleotides.

\section{ATP/ADP ratio}

ATP/ADP was assayed by measuring ATP and ADP in the same batch of islets with a modified method according to Johnson et al. (1970). At the end of the incubation period the medium was immediately removed by suction. Islets were disintegrated with $\mathrm{NaOH}(40 \mathrm{mmol} / \mathrm{l})$ / cysteine solution $(0.5 \mathrm{mmol} / \mathrm{l})$ and stored at $-20{ }^{\circ} \mathrm{C}$.

Each sample was divided into two parts. One part was incubated with a buffer containing creatine phosphate $(20 \mathrm{mmol} / \mathrm{l}) /$ glycine $(100 \mathrm{mmol} / \mathrm{l}) / \mathrm{MgSO}_{4}(1 \mathrm{mmol} / \mathrm{l})$ at $\mathrm{pH} 9 \cdot 0$ plus creatine kinase $(20 \mu \mathrm{g} / \mathrm{ml})$ for $10 \mathrm{~min}$ at room temperature before neutralization. The second part of the sample was incubated with the same buffer but without creatine kinase and neutralized at once with $3.3 \mathrm{mmol} / \mathrm{l}$ $\mathrm{HCl}$ to $\mathrm{pH} 7 \cdot 65$. Luminescence was measured after $20 \mathrm{~s}$ using an ATP assay kit 1243 (Bio-orbit, Turku, Finland) in a luminescence biometer 1253 (Bio-orbit). ATP standard curves were performed in the same buffers as described for the probes. (ATP and ADP were from Boehringer). ADP was determined in the same samples as used for the ATP assay by adding creatine phosphate/ creatine kinase (Gruber et al. 1974) and creating additional ATP by phosphorylation of ADP. The ATP was measured as described above with the bioluminescent assay. The ADP content was calculated as the difference between total ATP and ATP in each individual sample.

\section{Protein, DNA and insulin content}

For determination of protein, DNA and insulin content islets were stored at $-20{ }^{\circ} \mathrm{C}$ after the isolation procedure.

Protein The protein content of the pancreatic islets, solubilized with $0.1 \mathrm{~mol} / 1 \mathrm{NaOH}$, was measured using bovine serum albumin as standard (Bradford 1976).
DNA DNA quantification was performed according to Beckmann et al. (1981). Pancreatic islets were extracted with cysteine $(0.5 \mathrm{mmol} / \mathrm{l}) / \mathrm{NaOH} \quad(40 \mathrm{mmol} / \mathrm{l})$. For determination of DNA $50 \mu \mathrm{l}$ diaminobenzoic acid dihydrochloride solution were added to the samples and standards. After $40-\min$ incubation in a $60{ }^{\circ} \mathrm{C}$ waterbath the reaction was stopped with $1 \mathrm{~mol} / 1 \mathrm{HCl}$ and fluorescence was measured at $405 \mathrm{~nm}$ and $500 \mathrm{~nm}$ in a filter fluorimeter.

Insulin Extraction of insulin was performed according to the acid ethanol technique (Steinke \& Driscoll 1965), employing $50 \mu \mathrm{l}$ acid ethanol for each group of three islets. The islets were homogenized, frozen and neutralized with $0.1 \mathrm{~mol} / 1 \mathrm{NaOH}$. After dilution with Krebs-RingerHEPES buffer aliquots were taken and stored at $-20{ }^{\circ} \mathrm{C}$ until determination of insulin by RIA.

\section{Statistical analysis}

All values are given as means \pm s.E.M. for a certain number of separate experiments. The Student's $t$-test of unpaired data was used for statistical evaluation.

\section{Results}

In vivo experiments

In order to characterize the in vivo situation existing when pancreatic islets were exposed to chronic glucose infusion at the time of pancreas removal it was necessary to measure blood glucose and plasma insulin and to calculate the insulinogenic index over the period of infusion (not shown).

Chronic infusion of saline $(0 \cdot 45 \%, 2 \mathrm{ml} / \mathrm{h})$ over a period of $48 \mathrm{~h}$ had no significant effect on plasma glucose, plasma insulin and the insulinogenic index. When glucose $(50 \%$ in $0.45 \%$ saline, $2 \mathrm{ml} / \mathrm{h}$ ) was infused, the plasma glucose level was about $16 \mathrm{mmol} / 1$ after $24 \mathrm{~h}$. Despite further continuous infusion of the same quantity of glucose, the plasma glucose level declined to about $11 \mathrm{mmol} / 1$ after $48 \mathrm{~h}$. A $24-\mathrm{h}$ infusion of glucose produced a plasma insulin level of $500 \mu \mathrm{U} / \mathrm{ml}$ which declined to about $450 \mu \mathrm{U} / \mathrm{ml}$ after $48 \mathrm{~h}$ of infusion. The insulinogenic index increased from 0.45 to about 1.7 after $24 \mathrm{~h}$, and a further increase to $2 \cdot 0$ was seen after $48 \mathrm{~h}$.

In vitro studies

DNA, protein and insulin content Table 1 shows DNA, protein and insulin contents of pancreatic islets from SIR and GIR. The data indicate that in these islets DNA content was not significantly changed by glucose infusion whereas protein was increased significantly. However, insulin content of islets from GIR dropped to as little as 
Table 1 Pancreatic islet content of DNA, protein and insulin after a 48 -h infusion of saline or glucose. Values are means \pm S.E.M.

\begin{tabular}{|c|c|c|c|}
\hline & $\begin{array}{l}\text { DNA } \\
\text { ( } \mu \mathrm{g} / 10 \text { islets) }\end{array}$ & $\begin{array}{l}\text { Protein } \\
\text { ( } \mu \mathrm{g} / 10 \text { islets) }\end{array}$ & $\begin{array}{l}\text { Insulin } \\
\text { (ng/10 islets) }\end{array}$ \\
\hline Saline & $\begin{array}{l}0 \cdot 34 \pm 0 \cdot 04 \\
(n=16)\end{array}$ & $\begin{array}{l}3 \cdot 87 \pm 0 \cdot 40 \\
(n=10)\end{array}$ & $\begin{array}{l}528 \pm 41 \\
(n=8)\end{array}$ \\
\hline Glucose & $\begin{array}{l}0 \cdot 40 \pm 0 \cdot 04^{\mathrm{ns}} \\
(n=10)\end{array}$ & $\begin{array}{l}5 \cdot 75 \pm 0 \cdot 61^{*} \\
(n=7)\end{array}$ & $\begin{array}{l}104 \pm 23^{* * *} \\
(n=8)\end{array}$ \\
\hline
\end{tabular}

${ }^{*} P<0 \cdot 05,{ }^{* * *} P<0 \cdot 001$ compared with saline infusion. ns, not significant.

$20 \%$ compared with SIR. The data are in agreement with observations of others (Bedoya \& Jeanrenaud 1991a).

For the following in vitro studies islets of SIR, which served as controls, were prepared and preincubated either in the presence of 5.6 or $11.1 \mathrm{mmol} / 1$ glucose (see Materials and Methods) in order to test whether the glucose concentration present in the preparation and incubation media would affect insulin release, calcium uptake and metabolic parameters.

There being no significant difference between the two groups (data not shown) all islets in the following SIR experiments were prepared and preincubated at $5.6 \mathrm{mmol} / \mathrm{l}$ glucose - the physiological environment during the infusion period.
Insulin secretion (Fig. 1) Islets from SIR exhibited the typical sigmoid curve of insulin release in response to glucose. When islets from GIR were used insulin secretion in the presence of $2.8 \mathrm{mmol} / 1$ glucose was more than fourfold higher compared with SIR. Again, glucose increased insulin secretion in a concentration-dependent manner. However, distinct to islets from SIR, the maximal secretion rate was already achieved at $11.1 \mathrm{mmol} / \mathrm{l}$ glucose and further elevation of the glucose concentration did not produce additional discharge of insulin from islets of GIR.

In islets from SIR in the presence of $2.8 \mathrm{mmol} / 1$ glucose, $\mathrm{KCl}$ produced a concentration-dependent secretion of insulin. This was not the case when islets from GIR were employed, where secretion of insulin was already increased in the presence of $2.8 \mathrm{mmol} / 1$ glucose at the lowest concentration of $\mathrm{KCl}$ tested.

${ }^{45} \mathrm{Ca}^{2+}$ net uptake (Fig. 2) Islets from SIR exhibited a concentration-dependent increase of ${ }^{45} \mathrm{Ca}^{2+}$ net uptake in response to glucose. When islets from GIR were used basal ${ }^{45} \mathrm{Ca}^{2+}$ net uptake at $2.8 \mathrm{mmol} / 1$ glucose was nearly twofold higher compared with islets from SIR. Increasing the glucose concentration produced a concentrationdependent elevation of ${ }^{45} \mathrm{Ca}^{2+}$ net uptake, the maximum being achieved at $11.1 \mathrm{mmol} / 1$ glucose. Similar to the experiments on insulin secretion the concentrationresponse curve was shifted to the left. Further increase in
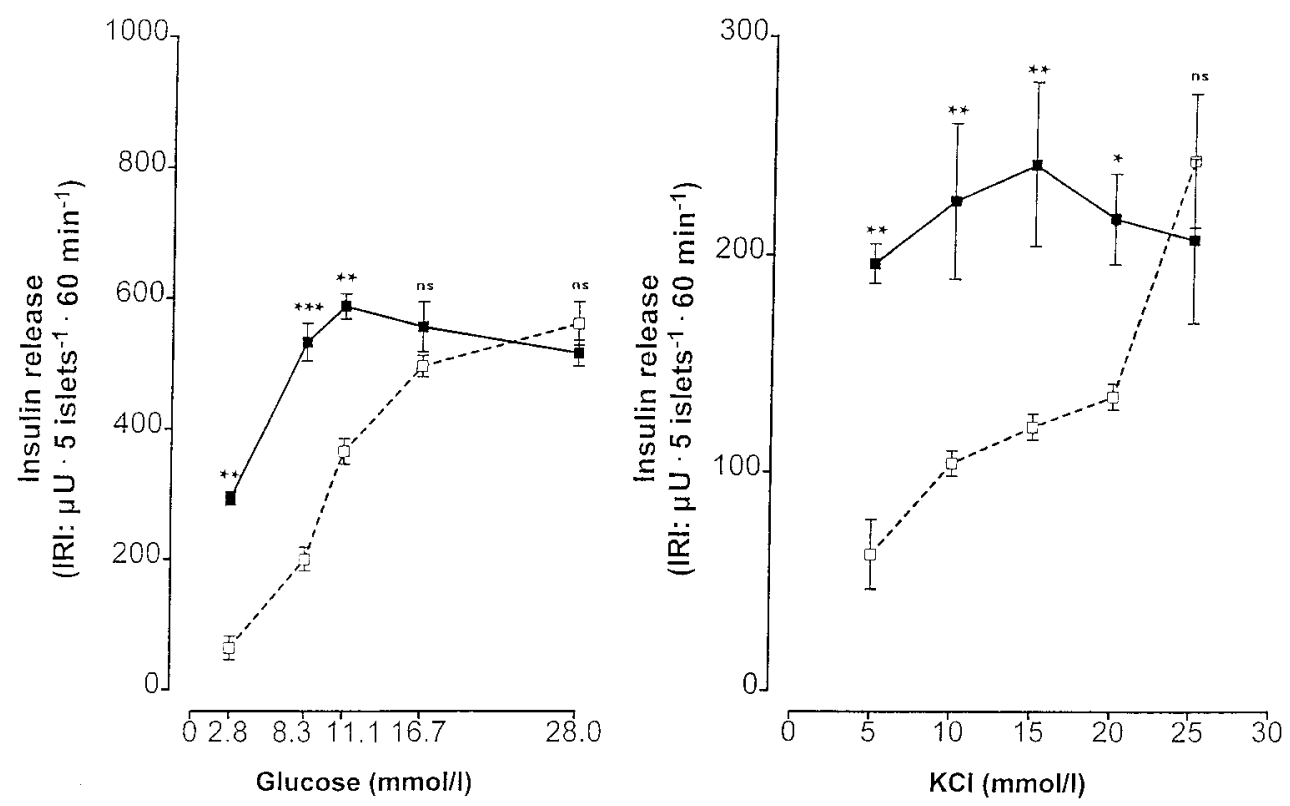

Figure 1 Effect of glucose and $\mathrm{KCl}$ on insulin secretion from pancreatic islets of rats after a 48-h infusion of glucose ( $\mathbf{\square})$ or saline $(\square)$. Batches of 5 islets were incubated in $1 \mathrm{ml}$ Krebs-Ringer-HEPES buffer $(\mathrm{pH} \mathrm{7 \cdot 4)}$ supplemented with various concentrations of glucose or $\mathrm{KCl}$ (in the presence of $2 \cdot 8 \mathrm{mmol} / \mathrm{l}$ glucose) for 60 min. Values are means \pm S.E.M., $n=4-5$. ${ }^{*} P<0 \cdot 05,{ }^{*} P<0 \cdot 01,{ }^{* *} P<0 \cdot 001$ : saline vs glucose or $\mathrm{KCl}$; ns, not significant; IRI, immunoreactive insulin. 

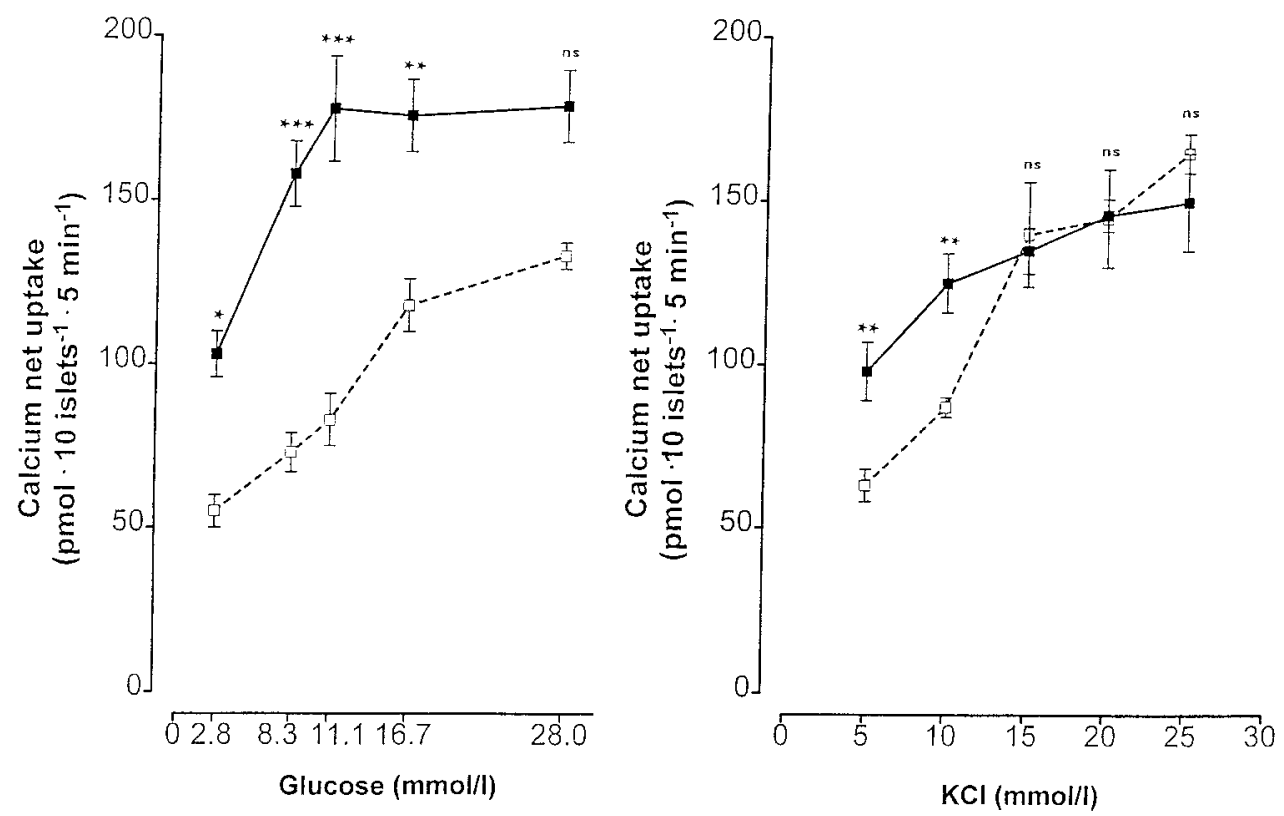

Figure 2 Effect of glucose and $\mathrm{KCl}$ on ${ }^{45} \mathrm{Ca}^{2+}$ net uptake into pancreatic islets of rats after a 48-h infusion of glucose $(\boldsymbol{\square})$ or saline ( $\square$ ). Batches of 10 islets were incubated in $0 \cdot 15 \mathrm{ml}$ Krebs-Ringer-HEPES buffer $(\mathrm{pH} 7 \cdot 4)$ and $0.80 \mathrm{MBq} / \mathrm{ml}^{45} \mathrm{CaCl}_{2}$ supplemented with various concentrations of glucose or $\mathrm{KCl}$ (in the presence of $2 \cdot 8 \mathrm{mmol} / \mathrm{l}$ glucose). Values are means \pm S.E.M., $n=6 .{ }^{*} P<0 \cdot 05,{ }^{* *} P<0 \cdot 01,{ }^{* *} P<0 \cdot 001$ : saline vs glucose or $\mathrm{KCl}$; ns, not significant.

the glucose concentration did not cause additional uptake of calcium.

In islets from SIR in the presence of $2.8 \mathrm{mmol} / 1$ glucose, $\mathrm{KCl}$ enhanced ${ }^{45} \mathrm{Ca}^{2+}$ net uptake in a concentration-dependent manner. This was not the case when islets from GIR were employed where ${ }^{45} \mathrm{Ca}^{2+}$ net uptake was already increased even at the lowest concentration of $\mathrm{KCl}$ tested in the presence of $2.8 \mathrm{mmol} / \mathrm{l}$ glucose.

${ }^{86} \mathbf{R b}^{+}$efflux (Fig. 3) As shown in Fig. 3A increasing glucose from 0 to $3 \mathrm{mmol} / 1$ produced only a marginal decrease of ${ }^{86} \mathrm{Rb}^{+}$efflux in islets from SIR. When the glucose concentration was increased from $3 \mathrm{mmol} / \mathrm{l}$ to $5.6 \mathrm{mmol} / 1$ the classical inhibition of ${ }^{86} \mathrm{Rb}^{+}$efflux was obvious and was reversed on return to $3 \mathrm{mmol} / \mathrm{l}$.

In contrast to the results obtained with islets from SIR, islets from GIR (Fig. 3B) showed abrupt significant inhibition of ${ }^{86} \mathrm{Rb}^{+}$efflux when the glucose concentration was increased from 0 to $3 \mathrm{mmol} / \mathrm{l}$, reaching approximately $1.75 \% / \mathrm{min}$, the effect being reversible. In a further experiment starting with $3 \mathrm{mmol} / 1$ glucose, ${ }^{86} \mathrm{Rb}^{+}$efflux from islets of GIR was lower than when starting with $0 \mathrm{mmol} / \mathrm{l}$. Elevation of glucose to $5.6 \mathrm{mmol} / \mathrm{l}$ again produced inhibition of ${ }^{86} \mathrm{Rb}^{+}$efflux declining to approximately $1.25 \% / \mathrm{min}$ which was reversible on return to $3 \mathrm{mmol} / \mathrm{l}$ glucose.
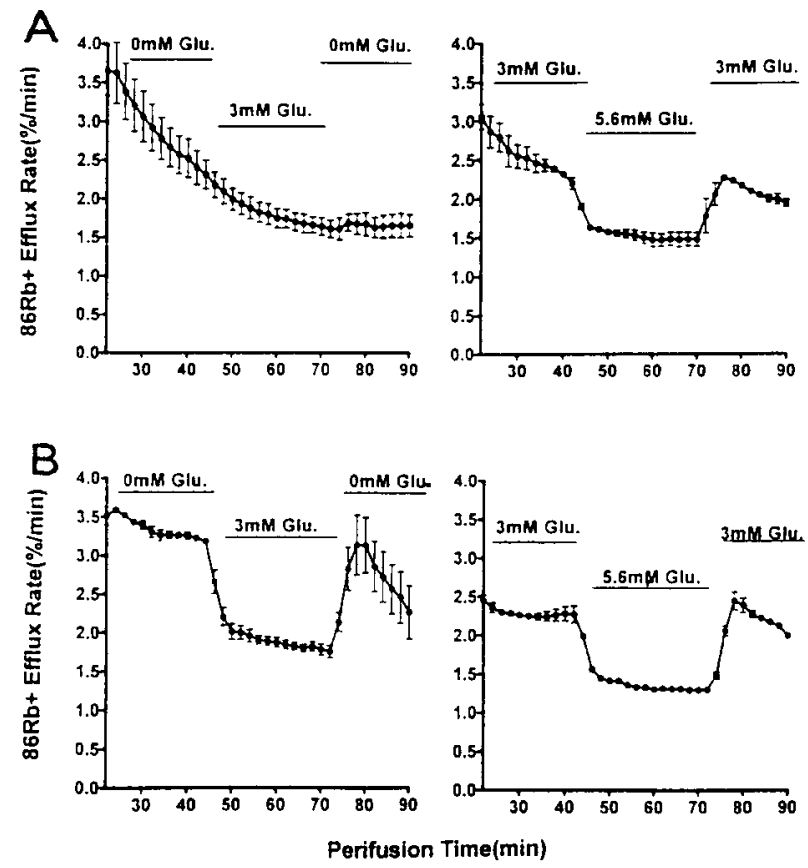

Figure 3 Effect of glucose on ${ }^{86} \mathrm{Rb}^{+}$efflux from pancreatic islets of rats after (A) 48-h infusion of saline and (B) 48-h infusion of glucose. Values are means \pm S.E.M., $n=3$. 


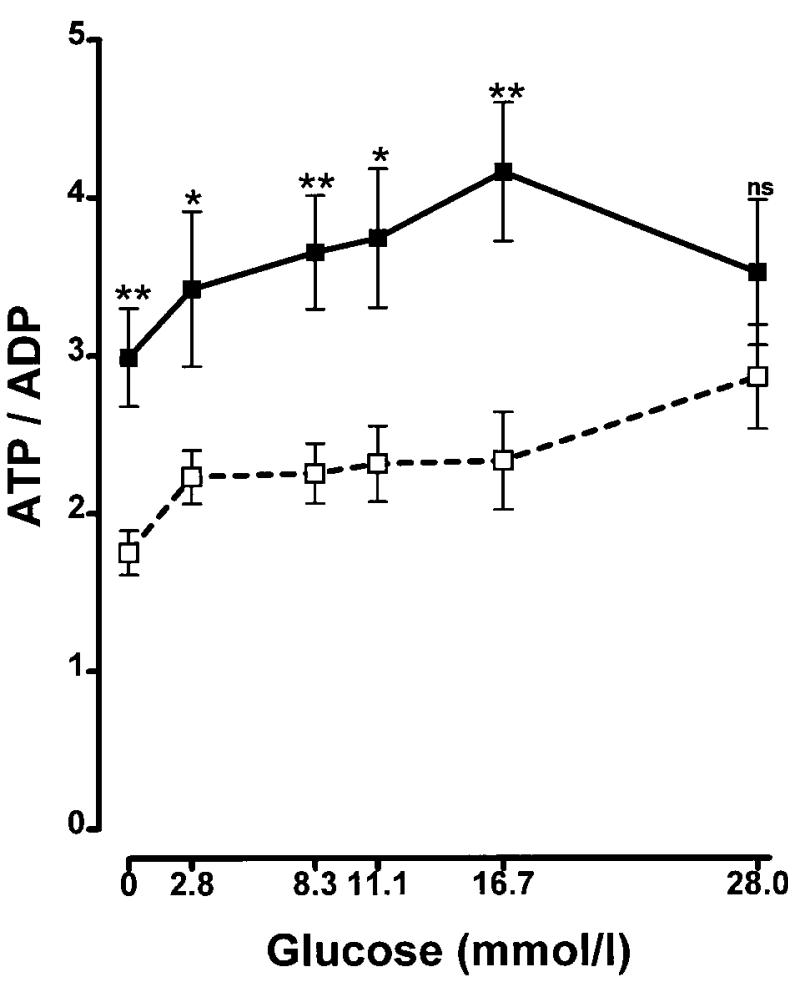

Figure 4 Effect of glucose on the ATP/ADP ratio in pancreatic islets of rats after a 48 -h infusion of glucose $(\boldsymbol{\square})$ or saline $(\square)$. Batches of 7 islets were incubated in Krebs-Ringer-HEPES buffer $(\mathrm{pH} \mathrm{7.4)}$ for $5 \mathrm{~min}$ in the presence of various glucose concentrations. Values are means \pm S.E.M., $n=7-8$. ${ }^{*} P<0 \cdot 05$, ${ }^{*} P<0 \cdot 01$ : saline vs glucose.

ATP/ADP ratio (Fig. 4) In islets obtained from GIR the ATP/ADP ratio was significantly higher than in islets from SIR, whether in the absence or in the presence of glucose. In both groups elevation of glucose produced a small rise in the ATP/ADP ratio. The total ATP+ADP was not significantly different in the two groups (not shown).

Pyridine nucleotides NAD-NADH (Fig. 5) Islets from GIR exhibited about 100\% higher total NAD+NADH than islets from SIR. Increasing the glucose concentration caused no significant change.

In islets from SIR addition of glucose to the incubation medium did not significantly change NAD levels. There was a tendency towards an increase in NADH which was, however, not of statistical significance (not shown). $\mathrm{NAD}+\mathrm{NADH}$ did not change. Only a small increase in the NADH/NAD ratio was observed.

In islets from GIR increasing the glucose concentration produced no significant change in NAD, but significantly enhanced the NADH levels to a maximum at $16.7 \mathrm{mmol} / 1$ glucose (not shown). Elevation of glucose
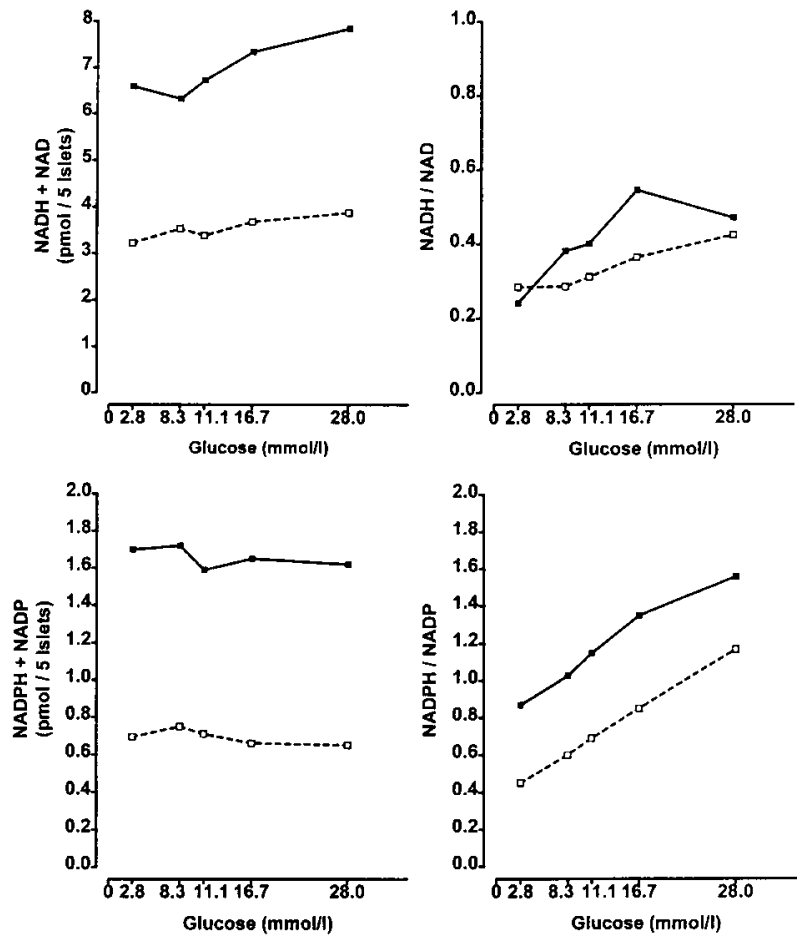

Figure 5 Effect of glucose on NAD+NADH, NADH/NAD, $\mathrm{NADP}+\mathrm{NADPH}$ and NADPH/NADP in pancreatic islets of rats after a 48-h infusion of glucose ( $\mathbf{\square})$ or saline ( $\square$ ). Batches of 5 islets were incubated in $1 \mathrm{ml}$ Krebs-Ringer-HEPES buffer $(\mathrm{pH} 7 \cdot 4)$ for 5 min containing various glucose concentrations.

concentrations did not affect total NAD+NADH but increased the NADH/NAD ratio to a greater extent than in islets from SIR.

NADP-NADPH (Fig. 5) Islets from GIR exhibited about $150 \%$ higher total NADP+NADPH levels compared with islets from SIR at all glucose concentrations tested. There was no concentration relationship. In islets from SIR glucose produced a slight concentration-dependent decrease in NADP and an increase in NADPH (not shown) which resulted in a marked elevation of the NADPH/NADP ratio. In islets from GIR starting from higher levels of NADP and NADPH at $2 \cdot 8 \mathrm{mmol} / 1$ glucose, elevation of the glucose concentration led to a small decline in NADP and an increase in NADPH (not shown). The NADPH/NADP ratio increased in a manner which paralleled and exceeded that observed in islets from SIR.

\section{Discussion}

The results of this study show that a 48-h glucose infusion which caused moderate hyperglycemia (about $11 \mathrm{mmol} /$ 1), decreased islets insulin content but sensitized insulin 
release in vitro in response to glucose, at least at glucose levels up to $11.1 \mathrm{mmol} / \mathrm{l}$. These observations are in accordance with data of others (Bedoya \& Jeanrenaud 1991b, Thams 1991, Purrello et al. 1992, Leahy et al. 1987) suggesting that hyperinsulinemia occurring during glucose infusion is due to increased sensitivity of the secretory mechanism in spite of the dramatic fall in the insulin content.

Sensitization of insulin secretion raises the question whether it is a common phenomenon being valid against any initiator of insulin release which causes depolarization or whether or not sensitization is restricted to depolarization by glucose. The data obtained with $\mathrm{KCl}$ showing no concentration-dependent effect on discharge of insulin and calcium uptake indicate that in islets of GIR sensitization of the secretory mechanism is limited to the initiating action of glucose. This interpretation is supported by observations of others (Bedoya \& Jeanrenaud 1991b) who reported that leucine, tolbutamide and $\alpha$-ketoisocaproate did not stimulate insulin release in islets from GIR. Since these compounds cause secretion of insulin by mechanisms which are different from that of glucose and do not include glucose metabolism it is obvious that sensitization of the secretory machinery has to do with glucose metabolism.

It has been reported that islets chronically exposed to high glucose exhibit increased glucose metabolism as indicated by enhanced glucose transporter affinity (Purello et al. 1992), $V_{\max }$ of glucokinase activity (Chen et al. 1994), glucose utilization (Bedoya \& Jeanrenaud 1991a) and glycogen production (Marynissen et al. 1990), and thus probably produce metabolic factors related to initiation and/or modulation of insulin secretion. In this context it was suggested that increased glycogen content causes hypersensitivity to glucose (Marynissen et al. 1990).

Critical factors in glucose metabolism are ATP and reduced pyridine nucleotides. In fact, as shown in this study, the ATP/ADP ratio as well as the redox ratios of pyridine nucleotides are increased in islets obtained from GIR. Whereas the ATP/ADP ratio is closely linked to $\mathrm{K}_{\text {ATP }}$ channels (Cook \& Hales 1984), it has been hypothesized that the redox systems of pyridine nucleotides are related to calcium uptake (Ammon \& Wahl 1994). Thus the raised ATP/ADP ratio in islets from GIR should decrease the threshold for glucose-induceable depolarization. That this is the case is evident from the data shown in Fig. 3, indicating marked inhibition of ${ }^{86} \mathrm{Rb}$ efflux in islets of GIR by as little as $3 \mathrm{mmol} / 1$ glucose.

Consequently, in islets from GIR at low $(2.8 \mathrm{mmol} / \mathrm{l})$ glucose, influx of calcium is increased when compared with islets from SIR.

Taking into account the fact that in islets from GIR in the presence of $3 \mathrm{mmol} / \mathrm{l}$ glucose potassium efflux is already inhibited and therefore calcium uptake is increased, it is plausible to assume that in these islets addition of $\mathrm{KCl}$ to the incubation medium is not able to cause depolarization and subsequent calcium uptake since in this case B-cells are already under depolarization.

It has been suggested that not only changes in the ATP/ ADP ratio but also other products deriving from glucose metabolism (Ammon \& Verspohl 1979, Ammon \& Mark 1985, Ashcroft et al. 1992, Ammon \& Wahl 1994), including increased redox state of pyridine nucleotides where the NADPH/NADP ratio is thought to be of special interest (Ammon \& Wahl 1994), may modulate calcium entry in response to depolarization. If this is true then the increase in these ratios in islets of GIR may contribute to increased calcium uptake finally resulting in enhanced insulin secretion.

As discussed above, a glucose concentration greater than $11.1 \mathrm{mmol} / 1$ possesses no additional secretory action in islets from GIR. It must, therefore, be assumed that these islets have lost sensitivity to high glucose. Desensitization of glucose-mediated insulin release following long term exposure to high glucose has been found to be associated with diminished glucose oxidation (Eizirik et al. 1992), decreased expression of mRNA of $\alpha_{1}$ subunit of voltagedependent calcium channels (Iwashima et al. 1993), decreased calcium uptake and cytosolic calcium in response to glucose (Okamoto et al. 1992, Anello et al. 1995). Whether this is also true for the decreased secretory response at high glucose in this study is not certain. Nevertheless, our observations that calcium uptake in islets of GIR does not follow a concentration-response relationship beyond $11.1 \mathrm{mmol} / \mathrm{l}$ glucose is not against such a possibility. Moreover, it is possible that the dramatic fall in the insulin content (Marynissen et al. 1990, Bedoya \& Jeanrenaud 1991a) does not allow further discharge of insulin when the glucose concentration exceeds $11.1 \mathrm{mmol} / 1$ (Steinke et al. 1972).

In conclusion, in pancreatic islets obtained from GIR glucose-induced insulin release is sensitized to glucose stimulation in vitro in a concentration range up to $11.1 \mathrm{mmol} / \mathrm{l}$ whereas this is not the case at higher glucose concentrations. Moreover, insulin secretion is not sensitized to KCl. Sensitization against glucose is, at least in part, due to enhanced glucose metabolism providing increased availability of critical factors including ATP and reduced pyridine nucleotides which in turn decrease the threshold for depolarization and enhance glucose-mediated calcium uptake.

\section{Acknowledgements}

The authors acknowledge the skilful technical assistance of Mrs I Hagenloh.

Part of this work has been presented at the Annual Meeting of the American Diabetes Association, Atlanta in 1995 and at the Annual Meeting of the European Society for the Study of Diabetes, Stockholm in 1995. 


\section{References}

Ammon HPT \& Verspohl EJ 1979 Effect of methylene blue on pyridine nucleotides and insulin secretion of rat pancreatic islets. Diabetologia 17 41-44.

Ammon HPT \& Mark M 1985 Thiols and pancreatic $\beta$-cell function: a review. Cell Biochemistry and Function 3 157-171.

Ammon HPT \& Wahl MA 1994 Islet redox ratios: their role in insulin release. In Frontiers of Insulin Secretion and Pancreatic B-cell Research, pp 113-112. Eds PR Flatt \& S Lenzen. London: Smith-Gordon.

Ammon HPT, Fahmy A, Mark M, Strölin W \& Wahl MA 1985 Failure of glucose to affect ${ }^{86}$ Rubidium efflux and ${ }^{45}$ Calcium uptake of fetal rat pancreatic islets. Journal of Physiology 385 365-372.

Anello M, Degano C, Rabuazzo AM, Caltabiano V, Patanè G. Vigneri R \& Purrello F 1995 Ionic flux abnormalities and glucoseinduced densensitization of rat pancreatic islets. Diabetologia $\mathbf{3 8}$ (Suppl 1) A110, Abstract No. 426.

Ashcroft FM, Williams B, Smith PA \& Fewtrell CMS 1992 Ion channels involved in the regulation of nutrient-stimulated insulin secretion. In Nutrient Regulation of Insulin Secretion, pp 193-212. Ed P Flatt. London: Portland Press.

Beckmann J, Lenzen S \& Panten U 1981 Quantification of cells in islets of Langerhans using DNA determination. Acta Diabetologica Latina 18 51-57.

Bedoya FJ \& Jeanrenaud B 1991a Evolution of insulin secretory response to glucose by perifused islets from lean (FA/FA) rats chronically infused with glucose. Diabetes 40 7-14.

Bedoya FJ \& Jeanrenaud B $1991 b$ Insulin secretory response to secretagogues by perifused islets from chronically glucose-infused rats. Diabetes 40 15-19.

Bolaffi JL, Bruno L, Heldt A \& Grodsky GM 1988 Characteristics of desensitization of insulin secretion in fully in vitro systems. Endocrinology 122 1801-1809.

Boyd AE 1992 The role of ion channels in insulin secretion. Journal of Cellular Biochemistry 48 234-241.

Bradford M 1976 A rapid and sensitive method for the quantitation of microgram quantities of protein utilizing the principle of proteindye binding. Analytical Biochemistry 72 248-254.

Chen C, Bumbalo L \& Leahy JL 1994 Increased catalytic activity of glucokinase in isolated islets from hyperinsulinemic rats. Diabetes 43 684-689.

Cook DL \& Hales CN 1984 Intracellular ATP directly blocks $\mathrm{K}^{+}$-channels in pancreatic B-cells. Nature 311 271-273.

Davalli AM, Pontiroli AE, Socci C, Bertuzzi F, Fattor B, Braghi S, Dicarlo V \& Pozza G 1992 Human islets chronically exposed in vitro to different stimuli become unresponsive to the same stimuli given acutely - evidence supporting specific desensitization rather than beta-cell exhaustion. Journal of Clinical Endocrinology and Metabolism 74 790-794.

Eizirik DL, Korbutt GS \& Hellerström C 1992 Prolonged exposure of human pancreatic islets to high glucose concentrations in vitro impairs the beta-cell function. Journal of Clinical Investigation 90 1263-1268.

Gruber W, Müllering H \& Bergmeyer HU 1974 Analytische Differenzierung von Purin- und Pyrimidin-Nucleotiden. In Methoden der enzymatischen Analyse, Band II, edn 3, pp 2128-2137. Ed HU Bergmeyer. Weinheim/Bergstraße: Verlag Chemie.

Henquin JC 1977 Tetraethylammonium potentiation of insulin release and inhibition of rubidium efflux in pancreatic islets. Biochemical and Biophysical Research Communications 77 551-556.

Henquin JC 1980 Tolbutamide stimulation and inhibition of insulin release: studies of the underlying ionic mechanisms in isolated islets. Diabetologia 18 151-160.

Henquin JC \& Meissner HP 1984 Significance of ionic fluxes and changes in membrane potential for stimulus-secretion coupling in pancreatic B-cells. Experientia 40 1043-1050.

Iwashima Y, Pugh W, Depaoli AM, Takeda J, Seino S, Bell GI \& Polonsky KS 1993 Expression of calcium channel mRNAs in rat pancreatic islets and downregulation after glucose infusion. Diabetes 42 948-955.

Johnson RA, Hardman JG, Broadus AE \& Sutherland EW 1970 Analysis of adenosine- $3^{\prime} 5^{\prime}$-monophosphate with luciferase luminescence. Analytical Biochemistry 35 91-97.

Lacy PE \& Kostianovsky M 1967 Method for isolation of intact islets of Langerhans from the rat pancreas. Diabetes 16 35-39.

Leahy JL \& Weir GC 1991 Beta-cell dysfunction in hyperglycaemic rat models: recovery of glucose-induced insulin secretion with lowering of ambient glucose level. Diabetologia 34 640-647.

Leahy JL, Cooper HE, Deal DA \& Weir GC 1986 Chronic hyperglycemia is associated with impaired glucose influence on insulin secretion: a study in normal rats using chronic in vivo glucose infusions. Journal of Clinical Investigation 77 908-915.

Leahy JL, Cooper HE \& Weir G 1987 Impaired insulin secretion associated with near normoglycemia. Study in normal rats with 96-h in vivo glucose infusions. Diabetes 36 459-464.

Malaisse WJ \& Sener A 1987 Glucose-induced change in cytosolic ATP content in pancreatic islets. Biochimica et Biophysica Acta 927 190-195.

Marynissen G, Leclercq-Meyer V, Sener A \& Malaisse WJ 1990 Perturbation of pancreatic islet function in glucose-infused rats. Metabolism 39 87-95.

Morgan CR \& Lazarow A 1963 Immunoassay of insulin: two antibody system. Plasma insulin levels in normal, subdiabetic and diabetic rats. Diabetes 12 115-119.

Okamoto Y, Ishida H, Taminato T, Tsuji K, Kurose T \& Tsuura Y 1992 Role of cytosolic $\mathrm{Ca}^{2+}$ in impaired sensitivity to glucose of rat pancreatic islets exposed to high glucose in vitro. Diabetes 42 1555-1561.

Passonneau JV \& Lowry OH 1974 Messung durch enzymatisches Cycling. In Methoden der enzymatischen Analyse, Band II, edn 3, pp 2108-2122. Ed HU Bergmeyer. Weinheim/Bergstraße: Verlag Chemie.

Purrello F, Buscema M, Rabuazzo AM, Forte E, Vetri M, Vinci C \& Caltabiano V 1992 Potential role of glucose transport in the mechanism of glucose-induced insulin release. Diabetes Nutrition and Metabolism 5 (Suppl 1) 9-14.

Soeldner JS \& Slone D 1965 Critical variables in the radioimmunoassay of serum insulin using the double antibody technique. Diabetes $\mathbf{1 4}$ 771-779.

Steinke J \& Driscoll SG 1965 The extractable insulin content of pancreas from fetuses and infants of diabetic and control mothers. Diabetes 14 573-578.

Steinke J, Patel TN \& Ammon HPT 1972 Relationship between glucose- and tolbutamide-induced insulin release and insulin content in single pancreatic rat islets. Metabolism 21 465-470.

Svensson C \& Hellerström C 1991 Long term effects of a high glucose concentration in vitro on the oxidative metabolism and insulin production of isolated rat pancreatic islets. Metabolism 40 513-518.

Thams P 1991 Role of protein kinase $\mathrm{C}$ and $\mathrm{Ca}^{2+}$ in glucose-induced sensitization/desensitization of insulin secretion. Experientia 47 1201-1208.

Thibault C, Guettet C, Laury MC, N'Guyen JM, Tormo MA, Bailbé D, Portha B, Pénicaud L \& Ktorza A. 1993 In vivo and in vitro increased pancreatic beta-cell sensitivity to glucose in normal rats submitted to a 48-h hyperglycaemic period. Diabetologia 36 589-595.

Timmers KI, Powell AM, Voyles NR, Solomon D, Wilkins SD, Bhathena S \& Recant L 1990 Multiple alterations in insulin response to glucose in islets from 48 -h glucose-infused nondiabetic rats. Diabetes 39 1436-1444.

Received 25 November 1996

Revised manuscript received 30 June 1997

Accepted 30 October 1997 